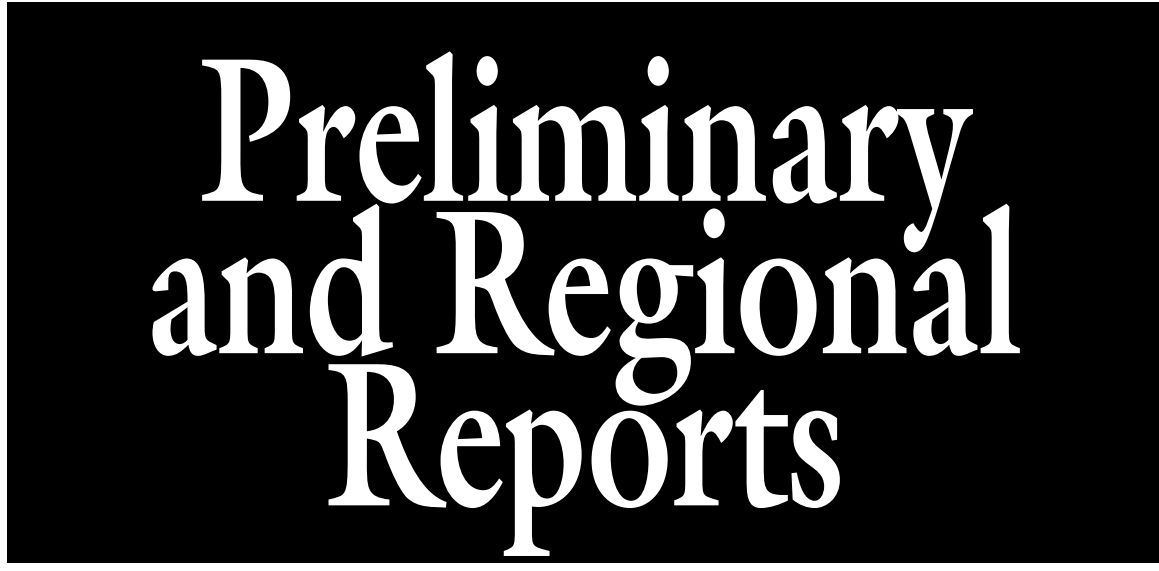

\section{Architectural Components of Compact Growth Habits in Diploid Roses}

\author{
Xuan $\mathrm{Wu}^{1}$, Shuyin Liang ${ }^{1}$, and David H. Byrne ${ }^{1}$
}

ADDITIONAL INDEX wORDs. flower productivity, garden rose, landscape, plant architecture, Rosa, yield

SUMMARY. Criteria to determine the horticultural quality of ornamental plants include plant architecture, flower characteristics, and resistance to biotic and abiotic stresses. The architecture of a rose (Rosa sp.) bush is linked to flower yield and ornamental value. The Texas A\&M University (TAMU) Rose Breeding and Genetics program has the objective of developing garden rose cultivars that flower heavily and exhibit a compact full shape. To determine which architectural traits are key for the development of this desired shape, five rose seedlings with a desirable compact growth habit and five with an undesirable growth habit were selected from TAMU diploid rose breeding germplasm. This comparison indicated that the key traits for the selection of compact growth habit are the number of primary shoots followed by the number of secondary and tertiary shoots produced.

I $\mathrm{n}$ the words of Alain Meilland in the foreword of the Encyclopedia of Rose Science: "no other flower is as universally loved and grown or has a more illustrious history than the rose" (Meilland, 2003). Rose is a member of one of the most important horticultural families, the rose

Received for publication 10 June 2019. Accepted for publication 15 July 2019.

Published online 9 September 2019

${ }^{1}$ Department of Horticultural Sciences, Texas A\&M University, College Station, TX 77843-2133

This work was partially funded by the Robert E. Basye Endowment in Rose Genetics and the U.S. Department of Agriculture's National Institute of Food and Agriculture Specialty Crop Research Initiative projects, "RosBREED: Combining Disease Resistance with Horticultural Quality in New Rosaceous Cultivars" and "Combating Rose Rosette Disease: Short Term and Long Term Approaches."

X.W. is the corresponding author. E-mail: jadexuanwu@ gmail.com.

This is an open access article distributed under the CC BY-NC-ND license (https://creativecommons.org/ licenses/by-nc-nd/4.0/).

https://doi.org/10.21273/HORTTECH04343-19 family (Rosaceae) and is admired for its great diversity of floral and plant characteristics. Sales of roses in 2014 in the United States generated $\$ 203.5$ million from the production of 36.6 million plants by 1808 growers (U.S. Department of Agriculture, 2015). According to the Green Industry Research Consortium National Survey, roses accounted for $3 \%$ of overall sales from 18 different horticultural production crop categories of the industry worth $\$ 25.9$ billion. Rose industry sales equate to contributions to the U.S. economy of $\approx \$ 777$ million. Most roses $(65 \%)$ are sold through retail outlets, with the remaining $35 \%$ of rose sales coming from landscape services (Green Industry Research Consortium, 2013). In North America, the economic impact of landscape roses in Canada was estimated at \$149 million, and the value in the United States was estimated at $\$ 928$ million (Vineland Research and Innovation Centre, 2013). The rose industry has a large economic impact worldwide.

Rose has four subgenera, more than 100 species (diploid through decaploid) and more than 30,000 commercial cultivars (mostly diploid, triploid, and tetraploid). These cultivars exhibit wide interspecific and intraspecific cross compatibility (Blechert and Debener, 2005; Byrne and Crane, 2003; Cairns, 2000; Jian et al., 2010; Spiller et al., 2011; Ueckert et al., 2015; Zlesak, 2009), and a broad diversity of flower and plant growth habits. Zuzek et al. (1995) described diverse growth habits of roses defining descriptors, including arching, climbing, dense, groundcover, open, rugosa, spreading, and suckering. Given this diversity of forms, the role roses play in landscapes is extensive. They are found adorning roadsides, public parks, commercial spaces, and residential areas. Garden roses provide aesthetic value throughout the growing season due to both their vegetative and floral production.

Plant architecture of roses is linked to flower yield and ornamental value (Crespel et al., 2014). Previous architectural analysis of roses focused on morphological, topological, and geometrical traits, such as stem length and diameter, succession, branching, and branching angles (Godin et al.,1999). Traits identified as relevant for characterizing rose bush shape include plant height, the number and length of stems, leaf profile, the internode length, branching angles, the branching site, and branch order number (Crespel et al., 2013; Gitonga et al., 2014; Kawamura et al., 2015; Morel et al., 2009; Wu et al., 2019). Little is known about which traits are critical

\begin{tabular}{llll}
\hline $\begin{array}{l}\text { Units } \\
\begin{array}{l}\text { To convert U.S. to SI, } \\
\text { multiply by }\end{array}\end{array}$ & U.S. unit & SI unit & $\begin{array}{l}\text { To convert SI to U.S., } \\
\text { multiply by }\end{array}$ \\
\hline 0.3048 & $\mathrm{ft}$ & $\mathrm{m}$ & 3.2808 \\
2.54 & inch(es) & $\mathrm{cm}$ & 0.3937 \\
1.6093 & mile $(\mathrm{s})$ & $\mathrm{km}$ & 0.6214
\end{tabular}


Table 1. Growth habits of parental lines from which diploid rose populations were developed.

\begin{tabular}{ll}
\hline Parent & Growth habit \\
\hline 'Basye's Thornless'z & Groundcover \\
'Old Blush' & Open bush \\
'Sweet Chariot' & Open bush \\
'Ducher' & Open bush \\
J06-30-3-6 & Groundcover \\
'Vineyard Song' & Spreading bush \\
M4-4 & Groundcover \\
J06-20-14-3 & Groundcover \\
'Red Fairy' & Spreading bush \\
\hline
\end{tabular}

${ }^{\mathrm{z}}$ Memorial rose (Rosa wichuriana).

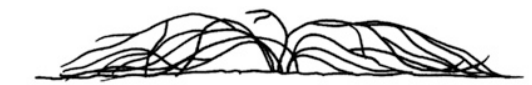

Ground cover (branches grow horizontally over the ground)

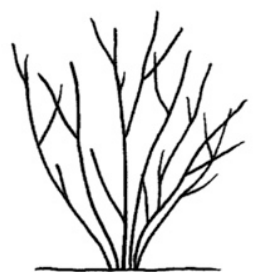

Open bush (erect plant with upright branches)

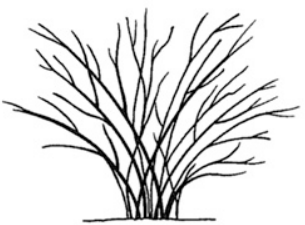

Spreading ( $v$-shaped plant with angled branches)

Fig. 1. Diverse growth habits of parental lines from which diploid rose populations were developed (Zuzek et al., 1995).

to the selection of specific bush shapes.

The focus of the TAMU Rose Breeding and Genetics program is the development of garden roses for the modern garden. One of the most important trends in home landscapes and gardens is low maintenance, in other words, easy-care (American Nurseryman, 2016). A rose that is low maintenance needs to be resistant to both biotic and abiotic stresses and have a full plant structure without consistent pruning. Recent surveys and studies indicate that consumer preferences for new rose traits include disease resistance, compactness, moderate height (from waist to shoulder height is preferable),
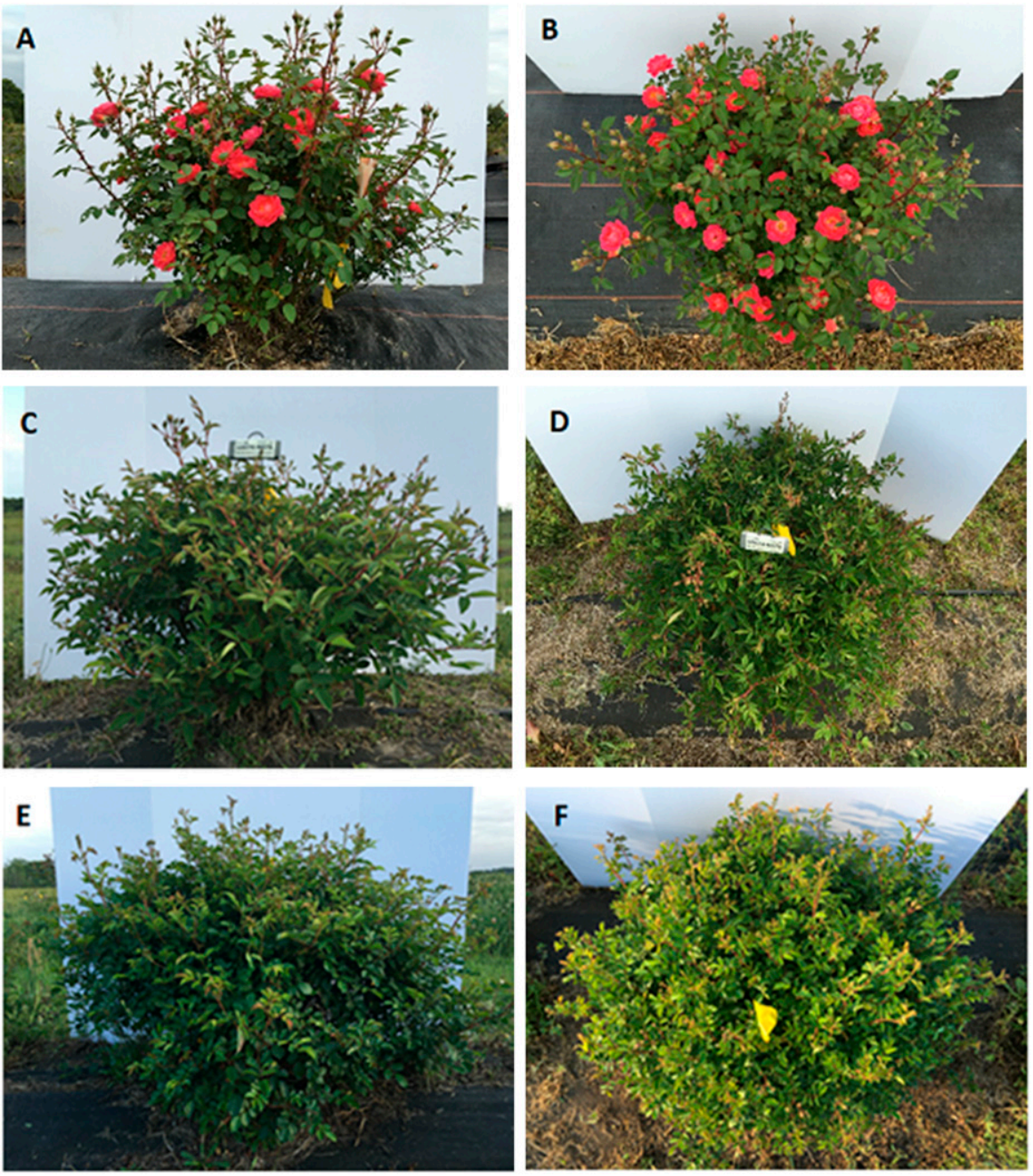

Fig. 2. Compact growth habit with evenly distributed, abundant flowers/shoots throughout the whole plant: $(\mathrm{A}, \mathrm{C}, \mathrm{E})$ side view, $(\mathrm{B}, \mathrm{D}, \mathrm{F})$ top view.
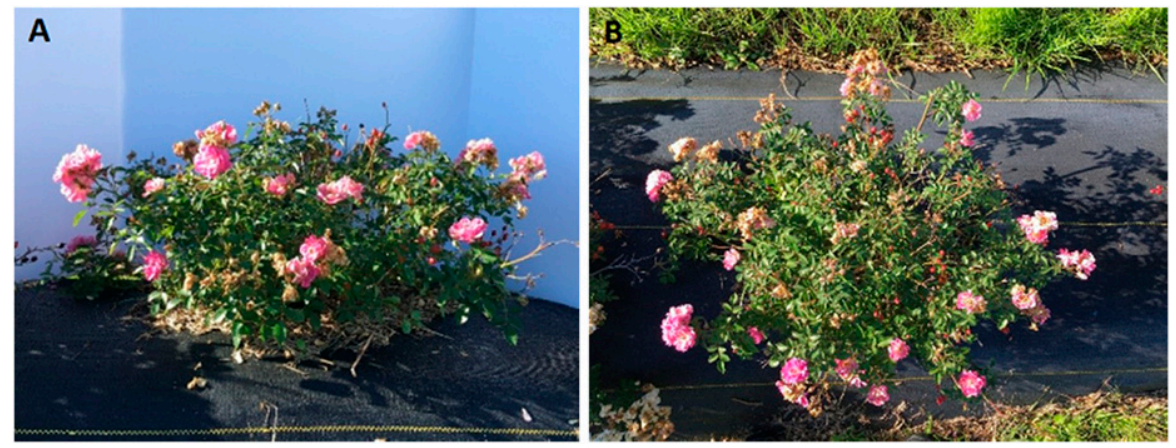

Fig. 3. Unnamed rose seedling with compact growth habit with undesirable perimeter flowers: (A) side view, (B) top view.

a high number of evenly distributed flowers, and fragrance (Boumaza et al., 2009; Chicago Botanic Garden, 2016; Lütken et al., 2015; Waliczek et al., 2018). The objectives of the Rose Breeding and Genetics sistant, heat-tolerant, compact plants with high flower count that are uniformly distributed on the plant and produced throughout the growing season. This research aims to identify
Program are to develop disease-re- 

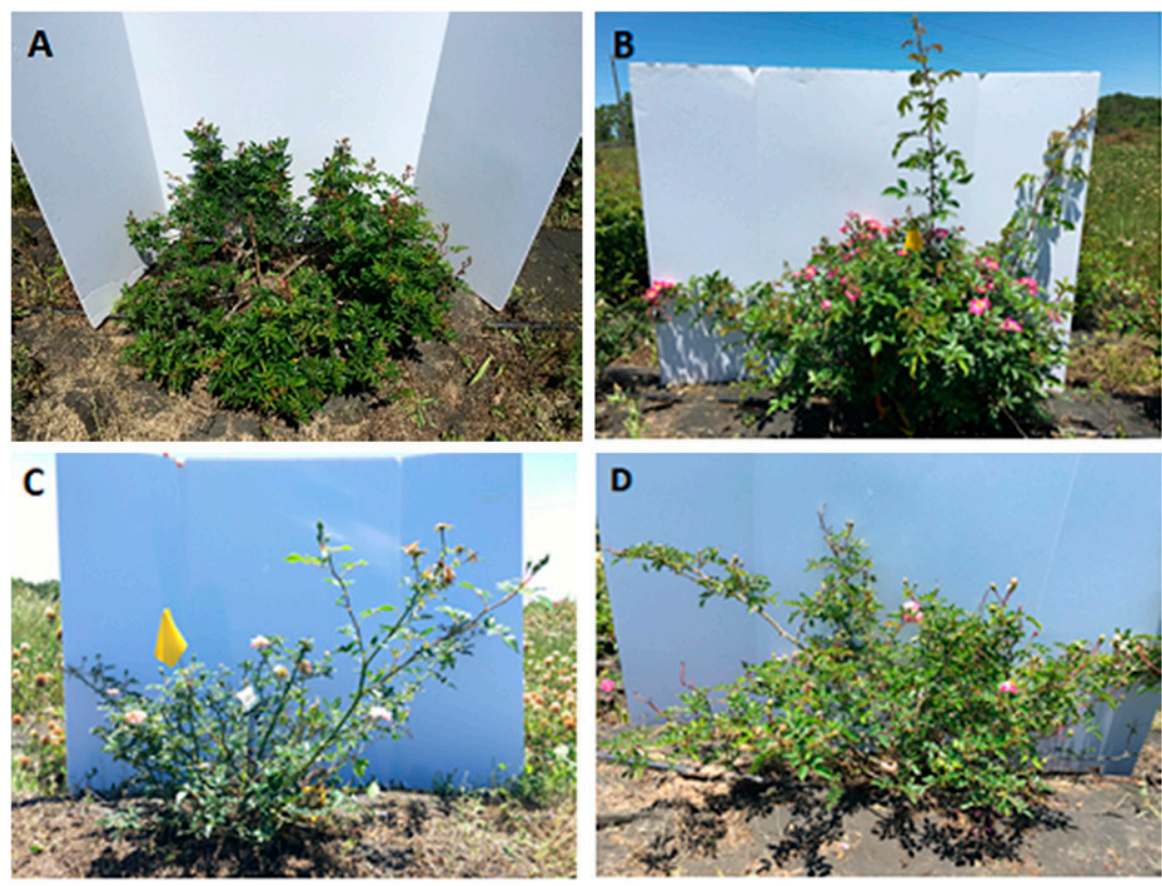

Fig. 4. Unnamed rose seedlings with undesirable growth habit: (A) an empty center, (B) long flower shoot, (C, D) noncompact and open shape.

the key growth traits responsible for the compact structure of the rose plant.

\section{Materials and methods}

Diploid rose populations derived from the hybridization of rose parents with diverse growth habits (Table 1, Fig. 1) (Wu et al., 2019; Zuzek et al., 1995) were planted in Mar. 2014 in double rows in a field $\approx 2$ miles from TAMU in College Station, TX (lat. $30.65^{\circ} \mathrm{N}$, long. $96.32^{\circ} \mathrm{W}$ ). Individual plants were planted at a $\mathrm{l} \times \mathrm{l} \times 3.5-\mathrm{m}$ spacing on raised beds in rows oriented east to west. Black cloth weed barrier was placed around the rose bushes for weed control. Irrigation was applied as needed to maintain sufficient moisture for good growth. No pesticides were applied during the evaluation. The roses were pruned in Mar. 2015 to remove dead tissue and to synchronize the growth of the seedlings. In December, at the end of the growing season in 2015 when the plants were $\approx 2$ years old, five rose seedlings with a desirable compact branching structure and five with an undesirable structure were selected. The desirable rose plants had a compact shape and evenly distributed, abundant flowers or shoots throughout the whole plant (Fig. 2). The undesirable rose plants had a plant form with an empty center [flowers on the outside and not in the middle of the plant (Figs. 3 and 4A)], long flowering shoots (Fig. 4B), and/or an open shape (Fig. 4C and D). All data were collected in $1 \mathrm{~d}$.

Six rose plant architectural traits were measured: plant height (centimeters), number of primary shoots (shoots that develop within 2 inches from the base of the plant), length of the primary shoots, number of nodes on the primary shoots, number of secondary shoots per primary shoot, and number of tertiary shoots per primary shoot. The means of the six architectural traits were compared between rose growth habits with a Student's $t$ test (JMP version 12; SAS Institute, Cary, NC).

\section{Results and discussion}

As seen in the characterization of the germplasm from which these plants were derived, substantial phenotypic variation was seen in plant height $(18-62 \mathrm{~cm})$, number of primary shoots (6-52 shoots per plant), primary shoot length $(26-62 \mathrm{~cm})$, number of nodes per primary shoot (6-13), and number of secondary/ tertiary shoots per primary shoot $(0-5 / 0-7$, respectively). These ranges are similar to what was reported in the germplasm level indicating the current sample is representative of the germplasm (Wu et al., 2019).

The comparison of the architectural traits between desirable compact and undesirable growth habits (Table 2 ) indicated that both types were similar in plant height, shoot length, and number of nodes per shoot. The key traits that differentiated these groups were primarily number of primary shoots and, secondarily, number of secondary and tertiary shoots produced. These traits determined the fullness of the plant, an important factor aesthetically. A rose plant with many primary shoots looked full; although, fewer primary shoots can be compensated for by more secondary and tertiary shoots. A desirable compact growth habit had more than 30 primary shoots, frequently combined with multiple secondary and tertiary shoots. This compact growth habit requires minimal pruning to maintain a symmetrical look.

The narrow sense heritability $\left(h^{2}\right)$ of these traits is relatively low $\left(\mathrm{h}^{2}=0.16\right.$ to 0.27$)$, whereas the broad sense heritability $\left(\mathrm{H}^{2}\right)$ varies from moderate [number of secondary/tertiary shoots per primary shoot $\left(\mathrm{H}^{2}=0.34 / 0.48\right.$, respectively $\left.)\right]$ to high [number of primary shoots $\left.\left(\mathrm{H}^{2}=0.92\right)\right]$ (Wu et al., 2019). Of the three traits, the number of primary shoots is most readily improved, as it has the highest additive and nonadditive genetic variance. Furthermore, given its low genotype $x$ environment $(G \times E)$ variance, selection would be effective during the first growth phase of the rose plant. The other two traits will be more challenging because of lower heritabilities and large $\mathrm{G} \times \mathrm{E}$ effects. Selection for the number of secondary/ tertiary shoots per basal shoot should be assessed during both growth phases and for substantial progress, additional germplasm with higher genetic variance for these traits may be required.

Identifying the key growth indicators of the number of primary and secondary/tertiary shoots simplifies selection and facilitates the development of new compact rose cultivars. The ultimate goal is to select rose plants that not only have compact growth, but also bloom consistently throughout the year. Future work should track the flowering behavior 
Table 2. The architectural traits of rose seedlings selected with desirable compact and undesirable growth habits evaluated in the field in Dec. 2015 at College Station, TX.

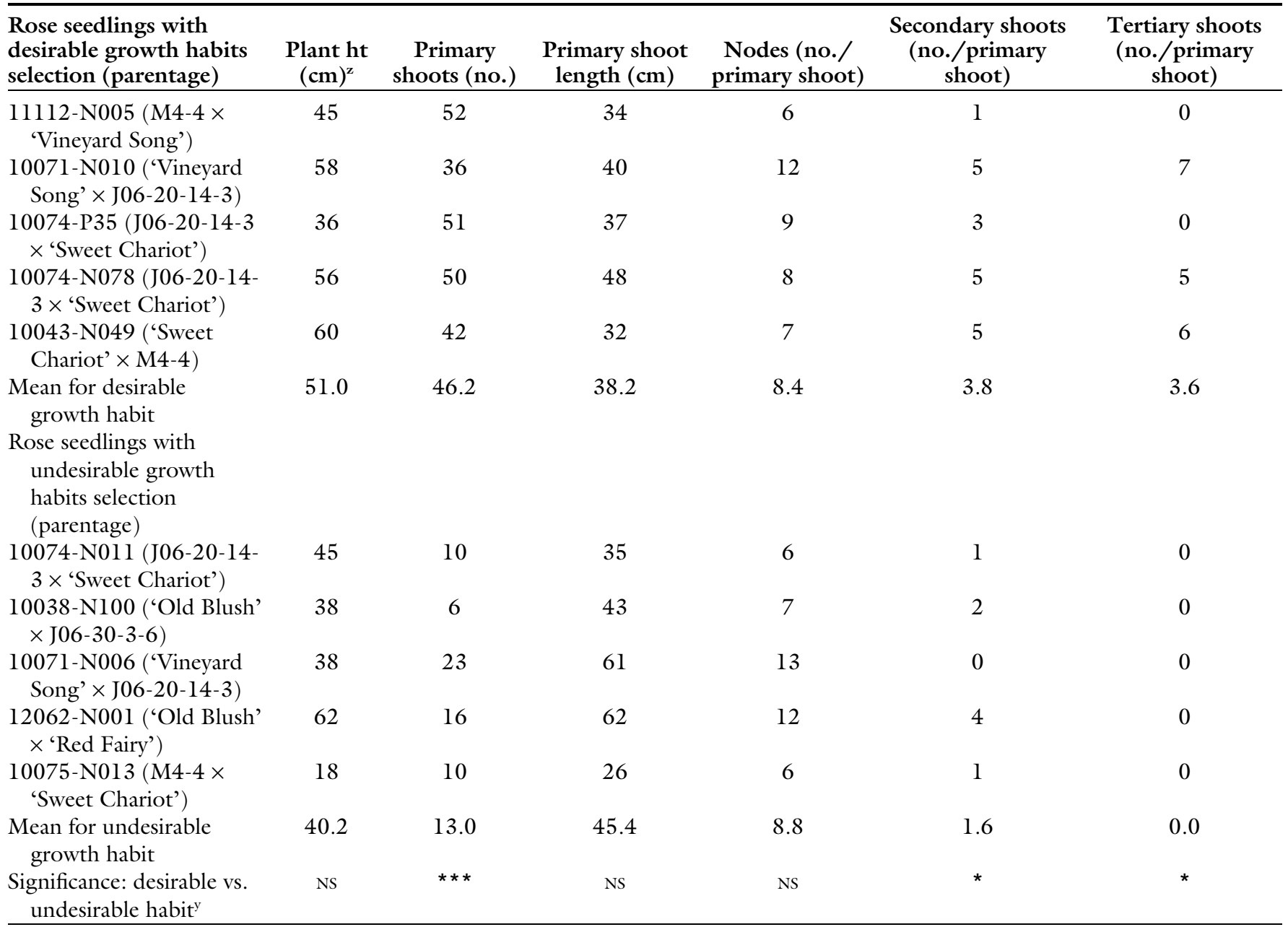

${ }^{\mathrm{z}} 1 \mathrm{~cm}=0.3937$ inch.

$\mathrm{y}_{\mathrm{NS}},{ }^{*},{ }^{* *},{ }^{* *}$ Nonsignificant or significant at $P \leq 0.05,0.01$, or 0.001 , respectively.

of the plant throughout the year to understand the relationship between shoot development and the pattern of flower opening among the various levels of inflorescences.

\section{Literature cited}

American Nurseryman. 2016. 6 Standout landscaping trends for 2016. 12 May 2017. <http://www.amerinursery.com/ landscape /six-standout-landscapingtrends-2016/>.

Blechert, O. and T. Debener. 2005. Morphological characterization of the interaction between Diplocarpon rosae and various rose species. Plant Pathol. 54:82-90.

Boumaza, R., S. Demotes-Mainard, L. Huché-Thellier, and V. Guérin. 2009. Visual characterization of the aesthetic quality of the rose-bush. J. Sens. Stud. 24:774-796.
Byrne, D.H. and Y.M. Crane. 2003. Meiosis, p. 273-279. In: A.V. Roberts, T. Debener, and S. Gudin (eds.). Encyclopedia of rose science. Elsevier, Oxford, UK.

Cairns, T. 2000. Modern roses XI, the world encyclopedia of roses. Academic Press, San Diego, CA.

Chicago Botanic Garden. 2016. Plant breeding. 25 July 2016. <http://www. chicagobotanic.org/research/ ornamental_plant_research/plant_ breeding $>$.

Crespel, L., C. Le Bras, D. Relion, and P. Morel. 2014. Genotype $\times$ year interaction and broad-sense heritability of architectural characteristics in rose bush. Plant Breed. 133:412-418.

Crespel, L., M. Sigogne, N. Donès, D. Relion, and P. Morel. 2013. Identification of relevant morphological, topological and geometrical variables to characterize the architecture of rose bushes in relation to plant shape. Euphytica 191:129-140.

Gitonga, V.W., C.F. Koning-Boucoiran, K. Verlinden, O. Dolstra, R.G. Visser, C. Maliepaard, and F.A. Krens. 2014. Genetic variation, heritability and genotype by environment interaction of morphological traits in a tetraploid rose population. BioMed Central Genet. 15: 146-159.

Godin, C., E. Costes, and H. Sinoquet. 1999. A method for describing plant architecture which integrates topology and geometry. Ann. Bot. 84:343-357.

Green Industry Research Consortium. 2013. Trade flows and market practices within the U.S. nursery industry, 2013. 9 June 2019. <http://saaesd.ncsu.edu/ docs / National\%20Green\%20Industry\% 20Survey $\% 20$ report $\% 202014 \% 20$ SCSB $\%$ 2052615.pdf>.

Jian, H., H. Zhang, K. Tang, S. Li, Q. Wang, T. Zhang, X. Qiu, and H. Yan. 
2010. Decaploidy in Rosa praelucens Byhouwer (Rosaceae) endemic to Zhongdian plateau, Yunnan, China. Caryologica 63:162-167.

Kawamura, K., L. Hibrand-Saint Oyant, T. Thouroude, J. Jeauffre, and F. Foucher. 2015. Inheritance of garden rose architecture and its association with flowering behaviour. Tree Genet. Genomes 11:1-12.

Lütken, H., J.N. Hegelund, M. Himmelboe, U.B. Lauridsen, and R. Müller. 2015. Natural transformation in plant breeding - A biotechnological platform for quality improvement of ornamental, agricultural and medicinal plants. Acta Hort. 1087:19-28.

Meilland, A. 2003. Foreword. In: A.V. Roberts, T. Debener, and S. Gudin (eds.). Encyclopedia of rose science. Elsevier, Oxford, UK.
Morel, P., G. Galopin, and N. Dones. 2009. Using architectural analysis to compare the shape of two hybrid tea rose genotypes. Scientia Hort. 120:391-398.

Spiller, M., M. Linde, L. Hibrand-Saint Oyant, C.-J. Tsai, D.H. Byrne, M.J.M. Smulders, F. Foucher, and T. Debener. 2011. Towards a unified genetic map for diploid roses. Theor. Appl. Genet. 122:489-500.

Ueckert, J., D.H. Byrne, K. Crosby, G. Hodnett, and D. Stelly. 2015. The utilization of the polyploid nature of roses. Acta Hort. 1064:73-78.

U.S. Department of Agriculture. 2015. Floriculture crops 2015 summary. 9 June 2019. <https://www.usda.gov/nass/ PUBS/TODAYRPT/floran 16.pdf $>$.

Vineland Research and Innovation Centre. 2013. The innovation report. Vineland Res. Innovation Ctr., Vineland Station, ON, Canada.
Waliczek, T.M., D.H. Byrne, and D.J. Holeman. 2018. Opinions of landscape roses available for purchase and preferences for the future market. HortTechnology 28:807-814

Wu, X., S. Liang, and D.H. Byrne. 2019. Heritability of plant architecture in diploid roses (Rosa sp.). HortScience 54:236239.

Zlesak, D.C. 2009. Pollen diameter and guard cell length as predictors of ploidy in diverse rose cultivars, species, and breeding lines. Floricul. Ornamental Biotechnol. 3:53-70.

Zuzek, K., M. Richards, S. McNamara, and H. Pellett. 1995. Performance of shrub and old garden roses at the Minnesota Landscape Arboretum. Minnesota Rpt., Univ. Minnesota, Agr. Expt. Sta., St. Paul, MN. 